\title{
KSZTAŁCENIE TŁUMACZY W ZAKRESIE FRAZEOTRANSLACJI
}

Zarys treści: W artykule podejęto kwestię przygotowania tłumaczy do radzenia sobie z przekładem szeroko pojętej frazeologii. Zasygnalizowane zostały problemy pojawiające się we frazeotranslacji oraz niektóre metody tłumaczenia struktur frazeologicznych. Ponadto przedstawiono wybrane strategie frazeodydaktyczne pomocne w kształceniu przyszłych tłumaczy.

\section{Wstęp}

U trwalone struktury językowe o charakterze reproduktywnym i często idiomatycznym stanowią poważne wyzwanie dla tłumaczy języków, którzy muszą skorelować je w różnych systemach językowych. Zakres tego typu struktur jest w językach naturalnych dość szeroki, ponieważ w zależności od przyjętej koncepcji frazeologii, wąskiej albo szerokiej, ich liczba waha się od kilku tysięcy do nawet kilku milionów (por. Bogusławski 1989; Denhière, Verstigel 1997). Ponadto sfrazeologizowane wytwory językowe zwykle są charakterystyczne tylko dla jednego, danego języka naturalnego, co czyni je szczególnie kłopotliwymi w procesie przekładu.

Współczesna frazeologia obejmuje swym zasięgiem struktury różnego typu, takie jak np.

- tradycyjne związki frazeologiczne,

- idiomy,

* Niniejszy tekst został opracowany w ramach prac naukowych finansowanych ze środków budżetowych na naukę w latach 2010-1012 jako projekt badawczy nr NN104 057439. 
- przysłowia i inne struktury paremiczne,

- wskaźniki frazeologiczne,

- kolokacje,

- terminologia specjalistyczna

- oraz inne odtwarzalne formy językowe.

Duża frekwencja takich struktur w językach naturalnych, a także ich specyficzne cechy składniowe i semantyczne sprawiają, że muszą one być specjalnie traktowane w procesach tłumaczenia. Na poziomie składniowym struktury frazeologiczne charakteryzują się nieciągłością elementów, co zaburza mechanizm ich linearnego przekładu, natomiast na poziomie semantycznym bardzo często znaczenie tych struktur jest idiomatyczne, czyli nie wynika z sensu składowych komponentów. Ten czynnik ma kluczowe znaczenie w przekładzie i pociąga za sobą po pierwsze problem właściwego odkodowania sensu, a następnie kwestię oddania tego sensu w języku docelowym z wykorzystaniem środków jezykowych możliwie najbliższych oryginałowi.

Wszystkie powyżej zasygnalizowane kwestie sprawiają, że przekład w zakresie frazeologii stanowi istotne zagadnienie zarówno ilościowe, jak i jakościowe. W konsekwencji naszym zdaniem można mówić nawet o frazeotranslacji, czyli o poddziedzinie przekładu, która byłaby zorientowana na tłumaczenie szeroko pojętej frazeologii i jej wytworów.

Frazeotranslacja implikuje także specyficzną dydaktykę przekładu, której celem jest przygotowanie przyszłych tłumaczy do sprawnego radzenia sobie $\mathrm{z}$ przekładem frazeologii.

\section{Strategie przekładowe we frazeotranslacji}

Tłumaczenie frazeologii jest na gruncie translatoryki tradycyjnie bardzo rzadko traktowane oddzielnie, choć obserwacja pracy tłumaczy pokazuje, że w praktyce miewają oni spore trudności właśnie z tą sferą języka.

Inspirując się pracą Rejakowej (1994), można przyjąć, że tłumacze w przekładzie frazeologii mają do dyspozycji kilka konkretnych strategii, a mianowicie:

Tłumaczenie jednostki frazeologicznej z języka wyjściowego za pomocą analogicznego frazeologizmu w języku docelowym

Jest to najbardziej słuszna i adekwatna strategia, która bezwzględnie powinna być stosowana w przekładzie homologów frazeologicznych oraz w większości przypadków korespondencji częściowej. Mechanizm ten pozwala na ogół zachować ten sam rejestr znaczeniowy, stylistyczny i ekspresy- 
wny pomiędzy oryginałem a przekładem. Przez pojęcie homologów frazeologicznych rozumiemy tu jednostki frazeologiczne w dwóch językach, które charakteryzują się najwyższym stopniem ekwiwalencji w każdym wymiarze. $\mathrm{W}$ konsekwencji ich przekład literalny jest możliwy z zachowaniem tego samego rejestru frazeologicznego i stylistycznego - np. polskie mieć związane ręce i francuskie avoir les mains liées. Natomiast korespondencja częściowa określa przypadki, w których jednostki charakteryzują się różnymi stopniami ekwiwalencji. Często w przypadku odpowiedników częściowych można mówić o ekwiwalencji semantycznej dotyczącej przenośnego, frazeologicznego znaczenia. I tak np. polski zwrot dać nogę to odpowiednik francuskiego lever le pied, choć metaforyczny sposób obrazowania oraz formalne środki językowe są tutaj bardzo różne. Odpowiedniki częściowe cechuje zazwyczaj ekwiwalencja frazeologiczna, tzn. jednostki języka wyjściowego i docelowego mają postać związków frazeologicznych. Natomiast nie możemy mówić tu o ekwiwalencji formalnej, zakładającej tożsamość elementów leksykalnych oraz analogię struktury gramatycznej.

Tłumaczenie frazeologizmu za pomocą jednego wyrazu w języku docelowym

Metoda ta może być stosowana, jeżeli w języku docelowym istnieje wyraz oddający w miarę dobrze sens i konotacje frazeologizmu z języka wyjściowego. Jednak takie podejście zubaża poziom stylistyczny i ekspresyjny oryginału i powinno być stosowane tylko w sytuacji absolutnej konieczności.

Tłumaczenie związków frazeologicznych za pomocą luźnego połączenia leksykalnego

Podobnie jak poprzednia strategia jest to metoda tzw. zła koniecznego. W obrębie stosowania tej techniki można wyróżnić właściwie dwie możliwe sytuacje:

- przekład kalkowany,

- tłumaczenie przez opis.

Stosowanie kalki frazeologicznej może czasem wzbogacić język docelowy, ale tylko pod warunkiem, że obrazowość i struktura językowa kalki mogą być zrozumiałe i przejrzyste dla odbiorców. Proceder kalki frazeologicznej musi więc być stosowany przez tłumacza bardzo ostrożnie i tylko wtedy, gdy dostrzega on zasadność oraz niepodważalne korzyści wynikające z jej użycia. Natomiast tłumaczenie przez opis implikuje zawsze zastosowanie innych środków językowych, które najczęściej pozwalają co najwyżej przekazać komunikacyjny sens oryginału, ale oddalają od niego przekład na poziomie stylistycznym. Przekład związków frazeologicznych za pomocą luźnego połączenia leksykalnego powinien więc być wybierany przez tłumaczy jedynie 
w sytuacji, gdy wymienione poprzednio strategie nie są możliwe do zastosowania.

Nie ulega wątpliwości, że najbardziej kłopotliwe na gruncie frazeotranslacji są idiomy oraz struktury frazeologiczne charakteryzujące się niskim poziomem międzyjęzykowej ekwiwalencji. Już w latach 70. XX w. Dzierżanowska (1977) w swojej pracy sygnalizowała, że idiomy są warstwą frazeologii najbardziej oporną na obce wpływy i dlatego najrzadziej przenoszą się z jednego języka do drugiego. W konsekwencji są one bardzo problematyczne w procesie tłumaczenia. Dzierżanowska (1977) postuluje, aby rozpatrywać oddzielnie przekład idiomów na język obcy i oddzielnie tłumaczenie ich na język ojczysty.

W przekładzie na język obcy:

- należy zastosować wyrażenie idiomatyczne tylko wtedy, gdy jest ono aktualnie używane. Tłumacz powinien być pewien aktualności wprowadzanego związku;

- nie należy wprowadzać idiomów z własnej inicjatywy, tzn. tłumaczyć wyrażenia prostego związkiem idiomatycznym.

Natomiast w przekładzie na język ojczysty:

- tłumacz łatwiej znajduje związek idiomatyczny w swoim języku ojczystym i rozróżnia jego aktualność,

- błędy najczęściej wynikają z niewłaściwego zrozumienia związku wyrazowego w języku oryginału,

- jeżeli brak odpowiednika idiomatycznego w języku docelowym, tłumacz powinien użyć innych środków językowych, np. formy opisowej.

Xatara (2002) postuluje, że tłumaczenie literalne we frazeologii jest możliwe wtedy, gdy frazeologizm z języka wyjściowego konceptualizuje się w identyczną strukturę w języku docelowym. Mamy wtedy do czynienia z sytuacją, w której zachowane zostają te same elementy leksykalne oraz taka sama struktura gramatyczna i składniowa, a także wywołany zostaje ten sam efekt komunikacyjny i ekspresyjny. Niemniej na gruncie frazeologii zdecydowanie częstsze jest tłumaczenie nieliteralne, konieczne np. w przypadku struktur idiomatycznych lub związków, które nie mają bezpośrednich ekwiwalentów w innym języku. W tej sytuacji można wyróżnić trzy możliwe przypadki:

- frazeologizm z języka wyjściowego tłumaczy się za pomocą podobnego, lecz nie identycznego frazeologizmu w języku docelowym,

- frazeologizm z języka wyjściowego tłumaczy się za pomocą całkiem innej struktury wyrazowej,

- frazeologizm z języka wyjściowego tłumaczy się za pomocą parafrazy. 
Tłumaczenie pozwala dostrzec we frazeologii niektóre kwestie, które są mniej widoczne w perspektywie jednojęzycznej. Moldoveanu (2001) wskazuje trzy różne możliwości transferu międzyjęzykowego struktur metaforycznych wykorzystywanych we frazeologii. Są one następujące:

- ekwiwalent w języku docelowym jest luźnym związkiem wyrazowym; $\mathrm{w}$ konsekwencji metafora z języka wyjściowego zanika,

- ekwiwalent w języku docelowym zawiera metaforę zleksykalizowaną pochodzącą z tej samej domeny semantycznej co w języku wyjściowym; jest to sytuacja dość częsta w przekładzie języków europejskich lub dość bliskich pod względem socjokulturowym,

- ekwiwalent zawiera metaforę zleksykalizowaną, ale domeny semantyczne w języku wyjściowym i docelowym są różne.

Transfer międzyjęzykowy frazeologizmów bazujących na metaforze implikuje konieczność stosowania różnych zabiegów językowych, takich jak np. różne reorganizacje gramatyczne i składniowe, interwencje na poziomie stylisytycznym, a nawet modyfikacje semantyczne i pragmatyczne.

Mejri (2009) słusznie twierdzi, że każdy przekład międzyjęzykowy stwarza ciągłe i regularne problemy z powodu różnic w kategoryzacji i gramatyczności języków, ale trudności te jeszcze się pomnażają w tłumaczeniu szeroko pojętej frazeologii. W tym przypadku dochodzi jeszcze wymiar idiomatyczny, procesy tropiczne, synteza oraz globalizacja semantyczna i składniowa, które nie są ani regularne, ani ewidentne w różnych kodach językowych.

We frazeologii można obserwować różny stopień gradacji skali skostnienia i utrwalenia językowego: z jednej strony sytuują się struktury o najwyższym poziomie sfrazeologizowania, a na drugim biegunie struktury o małym stopniu nieregularności i utrwalenia. Zależność tę ilustruje poniższy schemat.

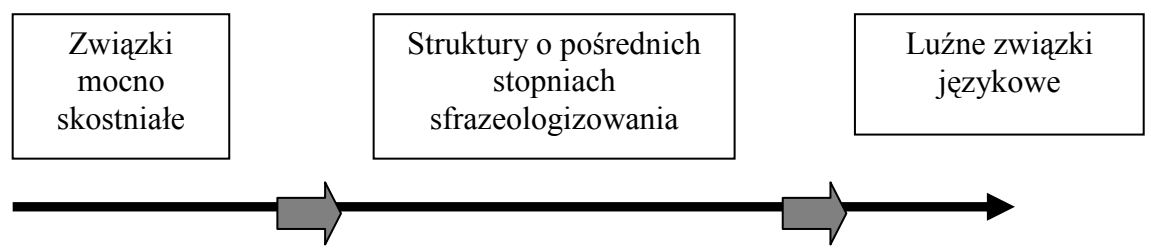

Schemat 1. Gradalny charakter frazeologii

Na gruncie frazeotranslacji można stwierdzić, że całkowite sfrazeologizowanie wbrew pozornym przypuszczeniom nie stanowi aż tak dużego problemu w przekładzie. W tym wypadku należy jedynie znać określoną grupę 
ekwiwalentów i traktować wielowyrazowe struktury właściwie podobnie jak pojedyncze leksemy (por. Mejri 2009 :156-157).

Natomiast tłumaczenie struktur o pośrednich stopniach sfrazeologizowania, takich jak np. różnego typu utrwalone kolokacje, jest już zadaniem znacznie trudniejszym, zwłaszcza że dochodzi tu jeszcze kwestia właściwego rozpoznania i wydzielenia takiej struktury w języku wyjściowym.

\section{Rozwijanie kompetencji frazeologicznych dla potrzeb frazeotranslacji}

Dydaktyka frazeologii nie ma zbyt dużej i utrwalonej tradycji, choć potrzebę rozwijania kompetencji frazeologicznych sygnalizowano już bardzo dawno (zob. np. Bally 1909: 73, Rey 1973, Jorge 1992, Mel'čuk 1993), a ostatnio jest ona wpisana także w ramy Europejskiego Systemu Opisu Kształcenia Językowego.

Mówiąc o pełnej kompetencji komunikacyjnej, Boyer (1995: 41-44) wskazuje na pięć mikrokompetencji składowych, takich jak:

- mikrokompetencja semiotyczna,

- mikrokompetencja referencyjna,

- mikrokompetencja dyskursywna i tekstowa,

- mikrokompetencja socjopragmatyczna,

- mikrokompetencja etnosocjokulturowa.

Sprawne wykorzystywanie sfery frazeologicznej języka wymaga przyswojenia wszystkich pięciu powyższych mikrokompetencji, a zwłaszcza dwóch ostatnich, które zarazem są najtrudniejsze w procesie uczenia się języka obcego.

Wéry (2000: 217-219) stawia kilka hipotez, które tłumaczą trudności w nabywaniu i rozwijaniu obcych kompetencji frazeologicznych. Pierwsza $\mathrm{z}$ nich wskazuje na potrzebę rozwoju dwóch ostatnich mikrokompetencji wymienianych przez Boyer (Wéry 2000: 217-219), a to z kolei implikuje konieczność bardzo dobrego opanowania języka obcego. Nabycie takich kompetencji jest możliwe właściwie przy dłuższych pobytach w obszarze używania danego języka lub co najmniej przy regularnym korzystaniu z obcojęzycznych środków masowego przekazu. Druga jego hipoteza (Wéry 2000: 217-219) określa brak motywacji, który jest znamienny dla nabywania kompetencji frazeologicznych. Frazeologia bywa obiegowo postrzegana jako pewien naddatek komunikacyjny, który nie jest niezbędny do komunikowania się w języku obcym. W konsekwencji uczniowie ani nawet nauczyciele języków nie akcentują potrzeby rozwiajania sprawności frazeologicznych, a struktury o po- 
średnich stopniach sfrazeologizowania, jak np. kolokacje, bywają po prostu pobieżnie traktowane $\mathrm{w}$ procesie dydaktycznym.

Wraz z trzecią hipotezą Wéry (Wéry 2000: 217-219) sygnalizuje brak narzędzi do produktywnego kształcenia $\mathrm{w}$ zakresie frazeologii. $\mathrm{Na}$ rynku dostępne są różnego typu słowniki frazeologiczne, jedno- i wielojęzyczne, ale są to narzędzia typu konsultacyjnego, pomagające jedynie w zrozumieniu struktur frazeologiczno-idiomatycznych. Natomiast brakuje ciągle opracowań frazeodydaktycznych, które rozwijałyby kompetencje frazeologiczne na poziomie produkcji. Tego typu podręczniki są bardzo niszowe, a traktowanie frazeologii w kompleksowych metodach do nauki języków jest również raczej marginalne.

Potrzeba rozwoju kompetencji frazeologicznych w procesie dydaktyki języka obcego powinna być obecnie postrzegana jako kwestia oczywista. Brak zrozumienia idiomatycznego języka naszego rozmówcy może powodować zaburzenia w procesie komunikacji werbalnej, w związku z czym każdy uczący się języka obcego powinien dążyć do opanowania frazeologicznych kompetencji receptywnych. Natomiast jeśli chodzi o poziom produkcji językowej, to najważniejsze jest tu przyswojenie tych związków wyrazowych, które są najbardziej bliskie i potrzebne w idiolekcie danego użytkownika. Potrzeby w zakresie kompetencji frazeologicznych wzrastają jednak wydatnie w przypadku tłumaczy, a także nauczycieli języków obcych, którzy powinni mieć wysoko rozwinięte kompetencje frazeologiczne nie tylko w zakresie recepcji, ale także na poziomie produkcji.

Kształcenie przyszłych tłumaczy nie może więc bagatelizować potrzeb $\mathrm{w}$ ramach frazeotranslacji. Odpowiedzialność tłumaczy we frazeologii jest bardzo duża:

- po pierwsze muszą oni poprawnie odkodować sfrazeologizowane struktury w języku wyjściowym,

- a po drugie muszą dokonać ich właściwego transferu do języka docelowego.

Colson $(1992,1995)$ z Instytutu Marie Haps w Brukseli, zajmującego się kształceniem tłumaczy ze specjalnym zwróceniem uwagi na frazeologię, proponuje kilka ścieżek dydaktycznych możliwych do stosowania w dydaktyce frazeotranslacji. Są to następujące strategie:

\section{Wyodrębnienie frazeologizmów}

Jest to pierwszy etap. Ma on na celu uwrażliwienie na frazeologię. Uczący się mają za zadanie zaznaczyć w tekście do tłumaczenia wszystkie struktury charakterystyczne dla tego języka, co powoduje zwrócenie ich szczególnej uwagi na ewentualne utrwalone i nieregularne związki wyrazowe lub użycia idiomatyczne. 


\section{Analiza semantyczna}

W następnym etapie działań wydzielone frazeologizmy stają się przedmiotem analizy z punktu widzenia ich znaczenia. Ten etap może być wzbogacony przez różnego rodzaju ćwiczenia z zakresu synonimów, antonimów i pól semantycznych.

\section{Analiza kontekstowa i makrostrukturalna}

W trzecim etapie przyszły tłumacz powinien rozpracować analizowane frazeologizmy w kontekście językowym i pozajęzykowym. Ten etap jest bardzo ważny zwłaszcza w przypadku związków idiomatycznych.

\section{Podejście teoretyczno-modularne}

Jest również rzeczą istotną, aby wzbogacić proces rozwijania kompetencji frazeologicznych przez tzw. podejście modularne. Przyszły tłumacz powinien np. gromadzić sobie własny indeks struktur pogrupowany tematycznie. Kolokacje i wyrażenia idiomatyczne powinny zajmować w nim miejsce szczególne, a ich użycia powinny być zilustrowane przykładami.

Ciekawe ćwiczenie frazeodydaktyczne, użyteczne w procesie kształcenia frazeotranslacji, proponuje także Mejri (2011). Wprowadza on, głównie w odniesieniu do frazeologii tekstów specjalistycznych, pojęcie tzw. pokrycia frazeologicznego (couverture phraséologique). Pokrycie frazeologiczne tekstu to stosunek sfrazeologizowanych struktur i kolokacji do ogólnej liczby leksemów w tym tekście. Można go zilustrować za pomocą wzoru

$$
\frac{\text { ogólna liczba wyrazów }}{\text { liczba frazeologizmów }}
$$

Koncepcja pokrycia frazeologicznego wydaje nam się interesująca z punktu widzenia dydaktyki frazeotranslacji, ponieważ można ją wykorzystać w ćwiczeniach polegających na porównywaniu pokrycia frazeologicznego tekstów w języku wyjściowym i docelowym.

Można podzielić ogólne pokrycie frazeologiczne na formy bardziej wyspecjalizowane, takie jak np. kolokacje, terminy specjalistyczne, idiomy itd.

Analizy kontrastywne bazujące na koncepcji pokrycia frazeologicznego, choć z pozoru dość banalne, mogą uwrażliwiać przyszłych tłumaczy na kwestię frazeotranslacji oraz być okazją do obserwacji funkcjonowania frazeologii w różnych kodach językowych. Uczący się mogą zaobserwować bezpośrednio zmiany w tekstach będące konsekwencją przekładu sfery frazeologicznej, a także wyrobić sobie nawyk wykorzystywania struktur frazeologicznych w swoich własnych przekładach.

Colson $(1992,1995)$ zwraca także uwagę na bardzo istotną w dydaktyce frazeologicznej rolę szeroko pojętego kontekstu, ważnego w przyszłej pracy 
tłumacza. Natomiast Wéry (2000) podkreśla zalety dokumentów autentycznych we frazeodydaktyce. Dokumenty autentyczne, zwłaszcza te pochodzące ze środków masowego przekazu, jak np. tytuły prasowe, fragmenty filmów, slogany reklamowe, mogą być bardzo dobrym źródłem struktur frazeologicznych, a ich wprowadzenie do procesów kształcenia językowego może być bardzo użyteczne, również jeśli chodzi o rozwijanie produktywnych kompetencji frazeologicznych, tak ważnych w wypadku tłumaczy.

\section{Konkluzja}

Nabywanie kompetencji frazeologicznych w języku obcym, zwłaszcza tych na poziomie produkcji, to proces względnie powolny, wymagający sporo wysiłku i zaangażowania. Przyswojenie tych kompetencji jest jednak niezbędne w przypadku aspirowania do pełnej znajomości języka obcego, a taka wymagana jest bez wątpienia u zawodowych tłumaczy. Naszym zdaniem proces uczenia się obcej frazeologii można podzielić na kilka etapów. Etapy te warto zilustrować za pomocą schematu:

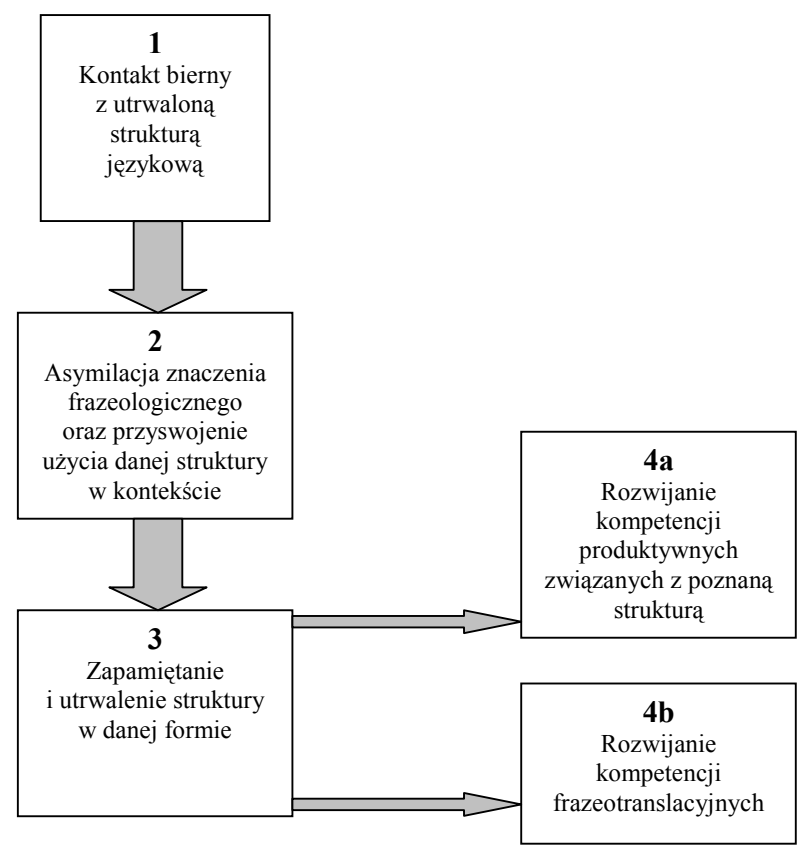

Schemat 2. Etapy uczenia się obcej frazeologii 
Etapy 4a i 4b odnoszą się do wyższego poziomu kompetencji frazeologicznych i powinny znaleźć swoje miejsce w kształceniu osób aspirujących do biegłej znajomości języka. Rozwijanie kompetencji produktywnych we frazeologii winno odbywać się przez różnego rodzaju ćwiczenia frazeodydaktyczne, a etap rozwijania kompetencji frazeotranslacyjnych powinien być wzbogacony przez strategie ukierunkowane na rozwój takich właśnie sprawności językowych.

\section{Literatura}

Bally, Ch., 1909, Traité de Stylistique française, v. I, II, Klincksieck, Paris.

Bogusławski, A., 1989, „Uwagi o pracy nad frazeologią”, [w:] Studia z polskiej leksykografii współczesnej III, Z. Saloni (red.), Białystok, s. 13-30.

Boyer, H., 1995, Éléments de sociolinguistique, Dunod, Paris.

Colson, J.-P., 1992, „Ébauche d'une didactique des expressions idiomatiques en langue étrangère", [w:] Terminologie et Traduction, 2/3, s. 165-181.

Colson, J.-P., 1995, „Quelques remarques sur l'enseignement de la phraséologie aux futurs traducteurs et interprètes", [w:] Le Langage et l'Homme, Vol. XXX, No 2-3, s. 147-156.

Denhière, G., Verstigel, J.-C., 1997, „Le traitement cognitif des expressions idiomatiques, activités automatiques et délibérées", [w:] La locution: entre lexique, syntaxe et pragmatique, Klincksieck, Paris, s. 119-148.

Dzierżanowska, H., 1977, Tłumaczenie tekstów nieliterackich. Założenia teoretyczne i wskazówki metodyczne, Warszawa, Wyd. UW.

Jorge, G., 1992, „Les expressions idiomatiques correspondantes: analyse comparative", [w:] Terminologie \& Traduction, 2-3, s. 127-134.

Mejri, S., 2009, „Figement, défigement et traduction. Problématique théorique", [w:] Figement, défigement et traduction, P. Mogorrón Huerta, S. Mejri (red.), Universidad de Alicante, s. 153-163.

Mejri, S., 2011, „Phraséologie et traduction des textes spécialisés”, http://192.168.170.5/pmb/catalog.php, Universidad de Alicante, Alicante, s. 125-137, (dostęp: 20 października 2011 r.).

Mel'čuk, I., 1993, „La phraséologie est son rôle dans l'enseignement / apprentissage d'une langue étrangère", [w:] Études de Linguistique Appliquée, 92, s. $82-113$.

Moldoveanu, M., 2001, „Structures métaphoriques dans la phraséologie: quels enjeux pour la traduction ?", [w:] Léloge de la différence: la voix de lautre, A. Clas, H. Awaiss, J. Hardane (red.), Série: Actualité Scientifique, s. 491-495. 
Rejakowa, B., 1994, Mechanizmy językowe w przekładzie związków frazeologicznych (na materiale języka polskiego i słowackiego), Rozprawy Habilitacyjne Wydziału Humanistycznego, LXXV, Lublin.

Rey, A., 1973, „La phraséologie et son image dans les dictionnaires de lâge classique", [w:] Mélanges de Linguistique Française et de Philologie et Littérature médiévales offerts à M. Paul Imbs, Klincksieck, Paris.

Wéry, L., 2000, „Approche des expressions idiomatiques en FLE”, [w:] Le Langage et l'Homme, Vol. XXXV, No 4, s. 215-232.

Xatara, C.M., 2002, „La traduction phraséologique”, [w:] Meta: journal des traducteurs, Vol. 47, No 3, s. 441-444.

\section{Coaching interpreters: translation of phraseological units Summary}

This paper probes into the ways of translating broadly defined phraseological units, the focus being on how to coach prospective interpreters who are to handle this kind of translation effectively.

Deeply rooted in natural languages, such multi-word reproductive units make up a great share of all utterances. As such, those units can be ignored neither in actual translation practice nor in the process of teaching translation.

Idiomatic phraseological units, typically very idiosyncratic in a given language, are a source of difficulty for interpreters faced with the necessity to relate them to those of a different language. It is argued that special note should be taken of phraseological structures in the process of translation while phraseological competences, both receptive and productive, should become part and parcel of every interpreter's working skills.

There are a number of procedures applicable to the translation of phraseological units. Coaching interpreters effectively involves the use of various methods and techniques conducive to developing active and passive phraseological competences. These strategies are described in the present paper. 